\title{
PARASITES IDENTIFICATION ON CORAL GROUPER (Plectropomus reolatus) IN FLOATING NET CAGE IN PAGIMANA SUB-DISTRICT OF BANGGAI REGENCY
}

\author{
Sri Sukari Agustina ${ }^{(1)}$ dan Fajar Setiawan J. ${ }^{(2)}$ \\ (1) Staf Pengajar Program Studi Budidaya Perairan \\ Fakultas Perikanan Universitas Muhammadiyah Luwuk ${ }^{(1)}$ \\ Jl. K.H. Ahmad Dahlan No. 79 Luwuk 94711 Kabupaten Banggai \\ Email address : asrisukari@yahoo.com \\ (2) Alumni Fakultas Perikanan Universitas Muhammadiyah Luwuk
}

\begin{abstract}
This research was conducted to know the kinds of parasites that attack of coral grouper (Plectropomus reolatus) in floating net cage in Pagimana Sub-district of Banggai Regency. The technique of collecting data of grouper in floating net cage in Jayabakti Village and Samajatem Village, Pagimana Sub-district is done randomly (Random Sampling), while for laboratory analysis is done at Station KIPM Class II Luwuk Banggai. The sample of grouper taken in the form of live fish in a state of almost died / collapse. Parasitic examination includes morphological observation, behavior, ectoparasite examination and endoparasit examination. The results of the identification of parasite that attacked of coral grouper (Plectropomus reolatus) on floating net cage in Pagimana subdistrict of Banggai Regency showed that the parasite species that attacked of coral grouper were Oodinium sp, Benedenia sp, Trichodina sp, Chilodonella spp, and Crepidostomum sp.
\end{abstract}

Keywords : parasites, floating net cage, Plectropomus reolatus

\section{PENDAHULUAN}

Ikan kerapu merupakan salah satu jenis ikan laut yang mempunyai prospek yang cukup baik untuk dikembangkan sebagai ikan budidaya karena mempunyai nilai ekonomis yang tinggi baik di pasaran lokal maupun internasional. Ikan kerapu juga potensial untuk dibudidayakan karena pertumbuhannya relatif cepat, mudah dipelihara, mempunyai toleransi yang tinggi terhadap perubahan lingkungan, dan tahan terhadap ruang terbatas misalnya dapat dilakukan pada suatu wadah terkontrol atau dapat dikembangkan pada suatu keramba jaring apung. Salah satu jenis ikan kerapu yang banyak dibudidayakan adalah ikan kerapu sunu (Plectropomus reolatus).

Kerapu sunu ( $P$. reolatus) merupakan ikan konsumsi laut yang mempunyai prospek pengembangan yang cukup cerah karena teknologi pembenihan massalnya telah dikuasai. Permintaan pasarnya dalam keadaan hidup sangat tinggi, baik di dalam maupun di luar negeri. Dalam rangka mendukung peningkatan produksi perikanan, khususnya ikan laut yang mempunyai nilai ekonomis tinggi seperti ikan kerapu sunu ( $P$. reolatus), akhirakhir ini sedang digalakkan pembudidayaannya dan mendapat perhatian masyarakat.

Sejalan dengan berkembangnya usaha budidaya ikan kerapu sunu tersebut, terdapat pula beberapa masalah yang mengganggu, sehingga menghambat perkembangan usaha budidaya. Kematian ikan kerapu sunu di keramba jaring apung dan kematian induk ikan kerapu sunu merupakan kendala yang sering dihadapi oleh pembudidaya. Kematian ikan kerapu sunu terjadi karena adanya penyakit, terutama dari golongan parasit.. 
Penyakit pada organisme perairan seperti halnya ikan kerapu didefinisikan sebagai sesuatu yang dapat mengganggu proses kehidupan ikan sehingga pertumbuhan tidak normal dan bahkan menyebabkan kematian. Secara umum penyakit dibedakan menjadi 2 (dua) kelompok yaitu penyakit infeksi dan non infeksi. Penyakit infeksi disebabkan oleh organisme hidup seperti parasit, jamur, bakteri, dan virus, serta penyakit non infeksi disebabkan oleh faktor non hidup seperti pakan, lingkungan, keturunan dan penanganan (Dalimunthe, 1989).

Penyakit akibat infeksi parasit menjadi ancaman utama keberhasilan akuakultur. Pemeliharaan ikan dalam jumlah yang besar dan padat tebar tinggi pada area yang terbatas, menyebabkan kondisi lingkungan tersebut sangat mendukung perkembangan dan penyebaran penyakit infeksi yang disebabkna oleh parasit. Kondisi dengan padat tebar tinggi akan menyebabkan ikan mudah stress sehingga menyebabkan ikan menjadi mudah terserang penyakit, selain itu kualitas air, volume air, dan alirannya berpengaruh terhadap berkembangnya suatu penyakit. Populasi yang tinggi akan mempermudah penularan karena meningkatnya kemungkinan kontak antara ikan yang sakit dengan yang sehat (Irawan, 2004).

Afrianto dan Liviawaty (1992) menyatakan bahwa timbulnya serangan parasit merupakan hasil interaksi yang tidak sesuai atau tidak serasi antara ikan, kondisi lingkungn, dan organisme atau agen penyebab penyakit yang disebabkan oleh parasit. Interaksi yang tidak serasi ini menyebabkan stress pada ikan, sehingga mekanisme pertahanan diri yang dimilikinya lemah, akhirnya agen penyakit mudah masuk kedalam tubuh dan menimbulkan penyakit yang disebabkan oleh parasit. Apabila keadaan tersebut tidak segera ditanggulangi lebih awal, maka kegiatan budidaya ikan kerapu terutama budidaya ikan kerapu sunu akan terganggu, akibatnya produktivitas ikan kerapu sunu akan menurun karena tingkat kematiannya tinggi.

Tujuan penelitian ini adalah untuk mengetahui jenis parasit yang menyerang ikan kerapu sunu ( $P$. reolatus) dalam keramba jaring apung di wilayah perairan Kecamatan Pagimana Kabupaten Banggai. Sedangkan kegunaan penelitian ini diharapkan dapat menjadi bahan informasi dalam budidaya ikan kerapu sunu $(P$. reolatus) khususnya informasi mengenai jenis-jenis parasit yang menyerang ikan kerapu sunu ( $P$. reolatus) di wilayah Kecamatan Pagimana Kabupaten Banggai.

\section{METODE PENELITIAN}

Penelitian ini dilaksanakan pada bulan Mei sampai dengan bulan Juli 2015 dengan dengan lokasi penelitian untuk pengambilan sampel ikan kerapu sunu di keramba jaring apung (KJA) Desa Jayabakti dan Desa Samajatem yang ada di wilayah perairan Kecamatan Pagimana Kabupaten Banggai, sedangkan untuk analisis laboratorium dilaksanakan di Stasiun KIPM Kelas II Luwuk Banggai. Metode yang digunakan untuk pengambilan data dalam penelitian ini adalah metode survei dan laboratories. Teknik pengambilan data sampel ikan kerapu sunu di keramba jaring apung yang ada di wilayah perairan Desa Jayabakti dan Desa Samajatem Kecamatan Pagimana dilakukan secara acak (Random Sampling), sedangkan waktu pengambilan sampel ikan kerapu sunu dilakukan dua tahap pada awal bulan Mei 2015 (musim kemarau) dan akhir Juni 2015 (musim hujan). Pengambilan jumlah sampel diambil sebanyak 5\% - 
10\% dari populasi ikan, dan dianggap sudah mewakili dari seluruh populasi ikan (Rokhmani dkk., 2004). Sampel ikan kerapu sunu yang diambil berupa ikan hidup dalam keadan hampir mati/kolaps. Pemeriksaan parasit meliputi pengamatan morfologi, tingkah laku, pemeriksaan ektoparasit dan pemeriksaan endoparasit. Hasil pemeriksaan parasit diidentifikasi berdasarkan Lucky (1977), Kabata (1985) dan Cruz-Lacierda (2001).

Sebagai data penunjang pengukuran parameter kualitas air berupa suhu, salinitas dan $\mathrm{pH}$ dilakukan pada saat pengambilan sampel ikan kerapu sunu. Untuk mengidentifikasi jenis-jenis parasit yang menyerang ikan kerapu sunu di keramba jaring apung Desa Jayabakti dan Samajatem yang ada di wilayah perairan Kecamatan Pagimana Kabupaten Banggai, semua data yang diperoleh dihimpun dalam bentuk tabulasi selanjutnya dianalisis secara deskriptif.

\section{HASIL DAN PEMBAHASAN}

\section{(A) Identifikasi Parasit Pada Ikan Kerapu Sunu}

Hasil pemeriksaan secara mikroskopis didapatkan jenis-jenis parasit yang menyerang ikan kerapu sunu di keramba jaring apung Desa Jayabakti dan Desa Samajatem yang ada di wilayah perairan Kecamatan Pagimana Kabupaten Banggai yaitu :

\section{a. Oodinium sp}

Hasil penelitian diperoleh bahwa parasit Oodinium sp ditemukan menginfeksi ikan kerapu sunu di Desa Jayabakti dan Desa Samajatem, penyakit oodinasis disebabkan oleh parasit dari kelompok protozoa jenis Oodinium pillularis dan Oodinium ocellatum. Protozoa ini tergolong dalam filum Sarcomastigophora, yang banyak menyerang berbagai jenis ikan hias air tawar. Namun, ternyata protozoa ini juga ditemukan menyerang ikan-ikan laut (Kordi, 2005).

Menurut Kordi (2005) serangan parasit ini dapat dikenali dari: gerakan ikan menjadi lemah, mengap-mengap di permukaan, dapat mengakibatkan kematian masal karena kerusakan di bagian kulit dan insang. Kerusakan ditandai dengan adanya pendarahan, inflamasi, dan nekrotis dibagian insang.

\section{b. Benedenia sp}

Parasit ini ditemukan menginfeksi ikan kerapu sunu di Desa Jayabakti dengan gejala klinis kehilangan nafsu makan, tingkah laku berenangnya lemah. Parasit ini termasuk Ordo Dactylogyridea, Famili Capsilidae. Monogenean Capsalid dikenal sebagai cacing kulit dan merupakan parasit

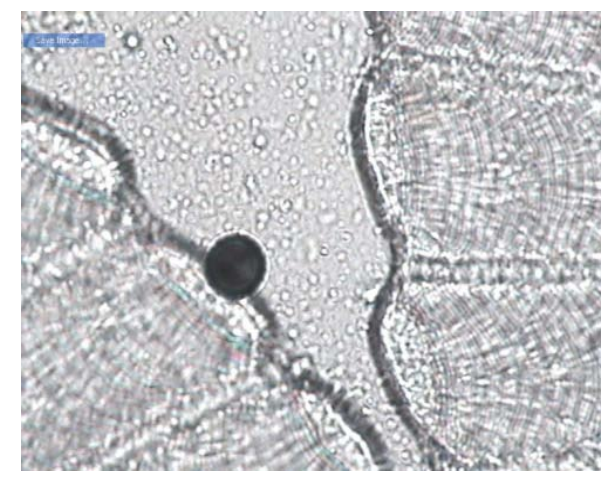

Gambar 1. Oodinium sp.

eksternal yang paling umum pada budidaya ikan laut. Capsalid meliputi beberapa spesies dan mempunyai kesamaan morphologi yaitu berbentuk oval (lonjong) dan gepeng dengan sepasang sucker bulat (anterior sucker) pada tepi bagian depan dan sebuah haptor besar (opisthapthor) pada tepi bagian belakang. Di Balai Besar Riset Perikanan Budidaya Laut Gondol, telah ditemukan beberapa jenis Capsalid yang didapat dari induk ikan-ikan kerapu, ikan napoleon dan ikan kakap. Neobenedenia girellae mempunyai tingkat patogenisitas yang lebih tinggi 
dibandingkan dengan Benedenia epinepheli, karena Neobenedenia girellae selain dapat menginfeksi kulit juga menyerang mata yang menyebabkan kebutaan (Zafran et al., 1998).

Ikan kerapu yang terinfeksi Neobenedenia girellae memperlihatkan gejala klinis; kehilangan nafsu makan, tingkah laku berenangnya lemah dan adanya perlukaan karena infeksi sekunder bakteri. Secara spesifik terlihat adanya mata putih keruh, yang menimbulkan kebutaan yang disebabkan oleh infeksi bakteri. Sebaliknya jenis Capsalid yang lain tidak meyebabkan

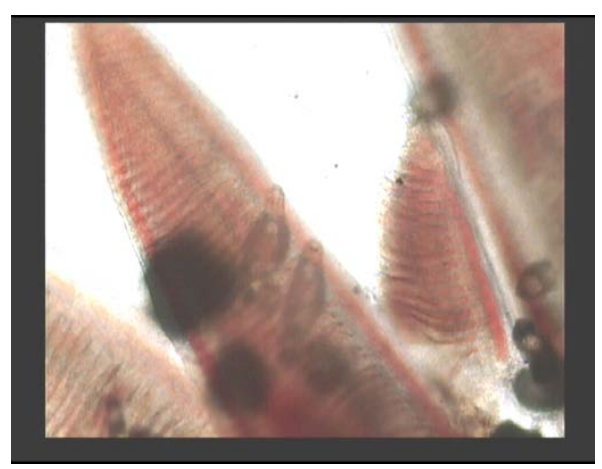

Gambar 2. Benedenia sp.

mata putih keruh pada ikan yang teinfeksi. Capsalid merupakan parasit yang tidak berwarna yang ada di permukaan badan ikan, sehingga sangat sulit untuk mengetahui adanya infeksi parasit. Untuk itu, merendamkan ikan beberapa menit dalam air tawar adalah cara yang sangat mudah untuk mengetahui adanya infeksi karena

parasit akan segera berubah warna menjadi putih didalam air tawar tersebut. Upaya pengendalian terhadap infeksi parasit ini, dianjurkan merendam dalam air tawar selama 10-15 menit atau dalam
$\mathrm{H}_{2} \mathrm{O}_{2} \quad 150$ ppm selama 30 menit (Zafran et al., 1998)

\section{c. Trichodina sp}

Dari hasil penelitian ditemukan parasit yang menginfeksi ikan kerapu sunu yang berasal dari Desa Jayabakti dan Desa Samajatem yaitu parasit Trichodina sp, dimana parasit Trichodina sp menyerang pada bagian insang, sisik dan lendir juga dari hasil pengamatan tingkah laku dan morfologi ditemukan ikan kerapu banyak mengeluarkan lendir, terdapat bintik putih keabuan pada bagian tubuh, adanya pendarahan pada bagian sirip dan tubuh ikan. Hal ini sesuai pendapat Afrianto dan Liviawati (1992) protozoa yang paling banyak menyerang ikan yang berada diperairan laut dan tawar adalah Trichodina sp, penyakitnya disebut Trichodiniasis, Trichodina sp menyerang pada bagian insang, sisik dan lendir.

Fernando et al. (1972) menyatakan bahwa setiap jenis parasit mempunyai habitat yang berbeda pada organ inang sebagai tempat hidupnya, ada beberapa ektoparasit yang menginfeksi dua atau lebih organ tubuh inangnya seperti Trichodina sp dapat menginfeksi sisik, sirip, kulit dan insang. Kabata (1985) menambahkan bahwa parasit Trichodina sp dapat menginfeksi, menempati dan berkembang biak pada habitat tertentu pada organ inangnya dan serangan parasit tersebut dapat terjadi pada dua atau lebih organ inangnya. Ikan yang terserang parasit Trichodina sp menjadi lemah dengan warna tubuh yang kusam dan pucat (tidak cerah), produksi lendir yang berlebihan dan nafsu makan ikan turun sehingga ikan menjadi kurus. 


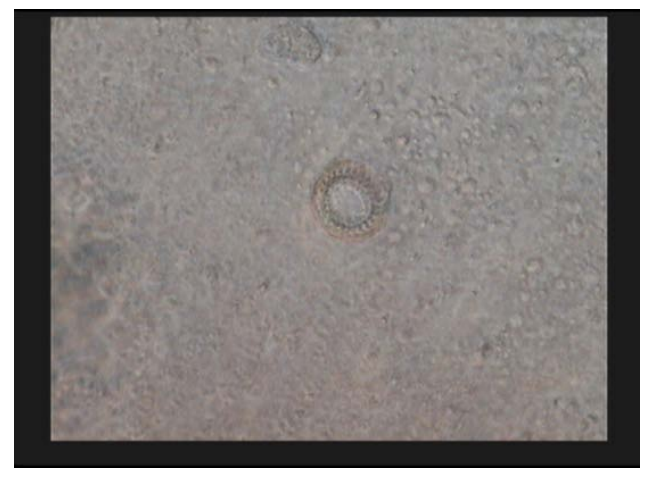

Gambar 3. Trichodina sp.

Pada hasil pengamatan penyerangan Trichodina sp diduga, karena kepadatan ikan di kolam yang tinggi sehingga proses pergesekan antar ikan yang terinfeksi terjadi, ikan mengalami stress akibat fluktuasi kualitas air karena perubahan musim dan pemberian pakan yang kurang atau tidak optimal. Disamping itu pada hasil pemeriksaan parasit, ikan kerapu yang terserang telah terserang parasit menurut pendapat Dwiyanto dan Suriawan (2006) bahwa pada dasarnya parasit ini bukan sebagai penyerang utama, tetapi ia menyerang pada ikan yang telah lebih dulu terkena parasit lain, misalnya karena luka, sakit, stress dan sebagainya, sehingga boleh dikatakan bahwa parasit ini sebagai infeksi sekunder.

\section{d. Chilodonella spp}

Hasil penelitian ditemukan yang menginfeksi ikan kerapu sunu yang berasal dari Desa Jayabakti dan Desa Samajatem yaitu parasit Chilodonella spp yang ditemukan menginfeksi lendir. Chilodonella spp ditemukan pada kulit, sirip dan insang ikan, kadangkala dalam jumlah banyak. Tanda-tanda klinis ikan terinfeksi Chilodonella spp antara lain ikan terlihat lemah, tidak mau makan, lendir berlebihan, perdarahan dan terjadi kerusakan epitel insang. Chilodonella spp menginfeksi ikan dan menyebabkan Chilodonellosis.

Parasit Chilodonella spp ditemukan menginfeksi lendir. Hal ini sesuai dengan Kabata (1985), bahwa
Chilodonella spp ditemukan pada kulit, sirip dan insang ikan, kadangkala dalam jumlah banyak, parasit ini menginfeksi kulit, sirip dan insang ikan dan kadangkadang dalam jumlah yang banyak. Faktor yang mendukung infeksi parasit ini adalah temperatur yang rendah yang dibantu dengan kurang bagusnya kondisi ikan. Parasit ini menempel pada tubuh inang dengan bantuan bulu getar (cilia) yang berada pada tubuh bagian ventral sedangkan pergerakannya didukung oleh adanya sederetan bulu getar pada tubuhnya. Gejala klinis : ikan yang terinfeksi menunjukkan gejala gerakan yang iritatif, meloncat kepermukaan air, tidak bereaksi atas stimulus rengsangan dan akhirnya ikan akan lemah. Ikan diselimuti lendir yang berwarna biru keabu-abuan.

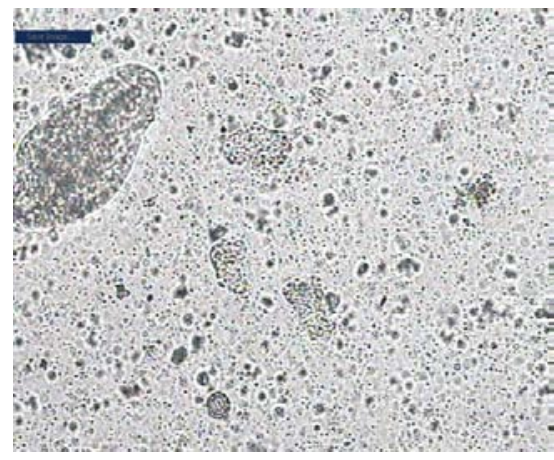

Gambar 4. Chilodonella spp.

\section{e. Crepidostomum sp}

Crepidostomum sp juga termasuk kedalam golongan cacing-cacingan. Seperti hal cacing-cacing yang lain, Crepidostomum sp juga berbadan bulat dan panjang, hewan ini berukuran 0,2 $0,5 \mathrm{~mm}$. Pada ujung anterior terdapat dua cuping. Setaip cuping memiliki kepala dan memiliki usus bercabang dua dimana ujungnya tidak bersatu parasit ini tidak memiliki vitelaria atau bersatu dengan ovari. Siklus Crepidostomum sp dari larva hingga menjadi dewasa membutuhkan waktu kira-kira 60 jam. Itu terjadi pada suhu $25-27{ }^{\mathrm{O}} \mathrm{C}$ (Zafran,1997). 


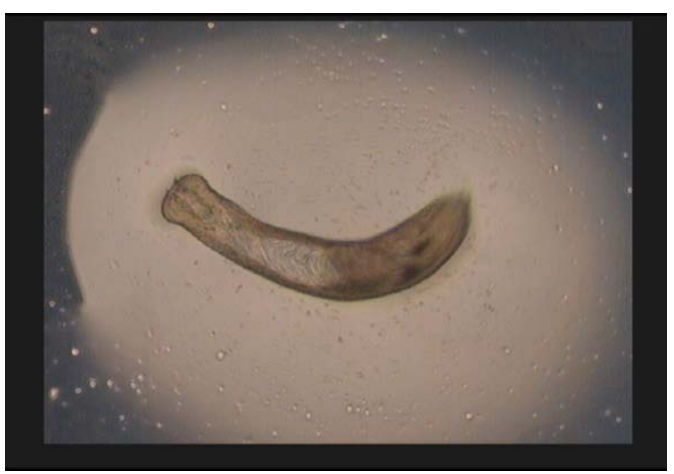

Gambar 5. Crepidostomum sp.

Parasit Crepidostomum sp disebut juga cacing insang, merupakan parasit yang cukup berbahaya dan sering ditemukan pada ikan laut. Seperti parasit Diplectanum, parasit ini juga diidentifikasi dari preparat segar insang secara mikroskopis menggunakan mikroskop. Parasit ini dapat diidentifikasikan berdasarkan bentuk karakteristik morfologinya. Ikan kerapu yang terinfeksi memperlihatkan gejala klinis; menurunnya nafsu makan, tingkah laku berenang yang abnormal pada permukaan air, warna tubuh berubah menjadi pucat. Serangan berat dari parasit ini dapat merusak filamen insang dan kadang-kadang dapat menimbulkan kematian karena adanya gangguan pernapasan. Warna insang ikan kerapu yang terinfeksi terlihat pucat (Zafran, 1997).

\section{(B) Kualitas Air}

Berdasarkan hasil pengamatan selama penelitian pada saat pengambilan sampel ikan kerapu sunu di keramba jaring apung (KJA) Desa Jayabakti dan Samajatem yang ada di wilayah perairan Kecamatan Pagimana Kabupaten Banggai didapatkan data rata-rata pengukuran kualitas air yaitu suhu dan $\mathrm{pH}$ yang tertuang pada Tabel berikut :

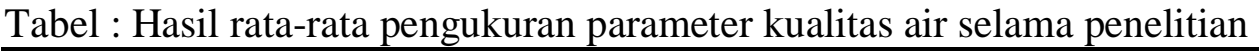

\begin{tabular}{lccccc}
\hline & & \multicolumn{4}{c}{ Lokasi KJA perairan } \\
\cline { 3 - 6 } No. & Variabel & \multicolumn{2}{c}{ Desa Jayabakti } & \multicolumn{2}{c}{ Desa Samajatem } \\
\cline { 3 - 6 } & & 33 & 35 & 34 & 35 \\
\hline 1 & Suhu $\left({ }^{0} \mathrm{C}\right)$ & 30 & 30 & 31 & 30 \\
2 & Salinitas (ppt) & 7,8 & 7,8 & 7,5 & 8 \\
3 & $\mathrm{pH}$ & &
\end{tabular}

Sumber : Data Primer (2015)

Berdasarkan hasil pengukuran suhu, salinitas dan $\mathrm{pH}$ yang diperoleh pada lokasi pengambilan sampel ikan kerapu sunu seperti tertera pada Tabel di atas, didapatkan bahwa suhu, salinitas maupun $\mathrm{pH}$ masih dalam kisaran yang layak untuk pertumbuhan ikan kerapu sunu. Hal ini sesuai dengan pernyataan Anonim (2001) untuk pertumbuhan dan kelangsungan hidup ikan kerapu, suhu harus dipertahankan antara $25-32{ }^{\circ} \mathrm{C}$, salinitas 20-32 ppt, pH 7,5-8,3. Menurut Chua dan Teng (1978) parameter ekologi yang cocok untuk pertumbuhan ikan kerapu adalah suhu yang berkisar antara 24-31 ${ }^{\circ} \mathrm{C}$, salinitas antara 30-33 ppt dan pH antara 7,8-8,0.

\section{KESIMPULAN}

Berdasarkan hasil penelitian dan pembahasan mengenai identifikasi parasit yang menyerang ikan kerapu sunu (Plectropomus reolatus) pada keramba jaring apung (KJA) di Kecamatan Pagimana Kabupaten Banggai dapat disimpulkan bahwa : 
- Jenis-jenis parasit yang menyerang ikan kerapu sunu yaitu Oodinium sp, Benedenia sp, Trichodina sp, Chilodonella spp, dan Crepidostomum sp.

- Data penunjang hasil rata-rata pengukuran parameter kualitas air yang meliputi suhu, salinitas dan $\mathrm{pH}$ di lokasi pengambilan sampel ikan kerapu sunu ( $P$. reolatus) pada keramba jaring apung di Kecamatan Pagimana Kabupaten Banggai masih dalam batas-batas yang layak untuk pertumbuhan dan budidaya ikan kerapu sunu dimana suhu $33-35{ }^{\circ} \mathrm{C}$, salinitas berkisar antara 30-31 dan $\mathrm{pH}$ berkisar antara 7,5-8.

\section{DAFTAR PUSTAKA}

Afrianto, E. dan E. Liviawaty. 1992. Pengendalian Hama dan Penyakit Ikan. Penerbit Kanisius, Jakarta.

Anonim. 2001. Pembudidayaan dan Managemen Kesehatan Ikan Kerapu. SEAFDEC Aquaculture Department. Kelompok Kerja Perikanan APEC, Aquaculture Departement Southeast Asian Fisheries Devel opment Center.

Chua, T. E. and S. K. Teng. 1978. Effects Of Feeding Frequency On The Growth Of Young Estuary Grouper, Epinephelus tauvina Forskal, Culture In Floating Net Cages. Aquaculture (14): 31-47.

Cruz-Lacierda, E. R. 2001. Parasitic Diseases and Pests. In Health Management in Aquaculture. Aquaculture Departement, Southeast Asian Fisheries Development Center. Phillipines: 55-73.
Dalimunthe,S.1989. Parasit dan Penyakit Ikan.Universitas Brawijaya Malang.

Dwiyanto,F.S dan Suriawan, A. 2006. Petunjuk Teknis Budidaya Kerapu di Keramba Jaring Apung. BBAP Situbondo.

Fernando et al. 1972. Methods for the Study of Freshwater Fish Parasites. University of Waterloo, Canada. Biology Series 12: 1-44.

Irawan, A. 2004. Menanggulangi Hama dan Penyakit Ikan. CV. Aneka. Solo.

Kabata, Z. 1985. Parasites and Diseases of Fish Culture in The Tropics. Taylor and Francis. London and Philadelphia. 318 p.

Kordi, M.G.H. 2005. Budidaya Ikan Laut di Keramba Jaring Apung. PT. Rineka Cipta. Jakarta. 233 hal.

Kuntinyo, R. 2004. Budidaya Ikan Kerapu. Aneka Ilmu. Semarang

Lucky, 1977. Methods For The Diagnosis of Fish Diseases. Amerind Publishing Co. PVT. Ltd. 140 p.

Rokhmani, dkk. 2004. Prevalensi Penyakit Parasit Pada Beberapa Benih Ikan Yang Dipasarkan Di Tempat Pelelangan Ikan Kembaran Purbalingga. Prosiding Seminar Nasional IV. Penyakit Ikan dan Udang. Balai Penelitian Ikan air Tawar. Purwokerto.

Zafran, D. Roza, I. Koesharyani, F. Johnny and K. Yuasa. 1998. Marine Fish and Crustaceans 
Diseases in Indonesia In Manual for Fish Diseases Diagnosis (Ed. by K. Sugama, H. Ikenoue and K. Hatai). 44 p. Gondol Research Station for Coastal Fisheries, CRIFI and Japan International Cooperation Agency. 